\title{
To Investigate Gender Based Difference in Undergraduate Students' L2 Integrative Motivation
}

\author{
Muhammadi Tanveer Ahmed \\ Mehran University of Engineering and Technology, Jamshoro, Hyderabad, Pakistan
}

Shoukat Ali Lohar

Mehran University of Engineering and Technology, Jamshoro, Hyderabad, Pakistan

Habibullah Pathan

Mehran University of Engineering and Technology, Jamshoro, Hyderabad, Pakistan

Received: April 9, 2019 Accepted: May 30, 2019 Published: July 1, 2019

doi:10.5296/elr.v5i2.15188 URL: https://doi.org/10.5296/elr.v5i2.15188

\begin{abstract}
This study took place in Shah Abdul Latif University Khairpur, Sindh Paksitan. This University is in the general category with 29 departments. Keeping in mind the regional context, a questionnaire containing adapted and adopted statements from Attitude Motivation Test Battery (AMTB) and other questionnaires of L2 (second language) motivation researchers was developed. The participants of the study were 350 students (178 males and 172 females) from first year of undergraduate courses. The study aimed at inquiring if there was gender-wise difference among the students in the integrative motivation for learning English. The L2 motivation study in the area of gender-wise differences has yet to accumulate in Pakistan. The worldwide literature on the topic also suggests dearth of it internationally and a variance in results. Traditionally, gender-based differences have been found in favour of females (scoring high in integrative and instrumental motivation). However, this study found no such difference.
\end{abstract}

Keywords: Integrative motivation, Gender, Undergraduate students, Second language motivation

\section{Introduction}

English language occupies central role in every world business. It is language of communication of all human activities which are deemed impossible to ignore and now are 
necessary condition of survival and progress to participate in. The official language in Pakistan is English. It is deemed essential requirement for leading a successful academic, professional or social life. Looking at the upward social mobility benefit from learning English language, there is always ever increasing demand of its learning. . Therefore, English is given paramount importance in the national curriculum of the country. Pakistani teachers of English go through various government-funded workshops and trainings for improved and updated practices in class room teaching.

Second language learning (L2) scholars have unanimous agreement that degree of achievement goes high or low with the degree of motivation in a second language. According to Gardner (1985) if the attitude is positive about the community whose language is being learnt then the learners will continue learning the language with increased periodical progress. If the teachers are skilled in their teaching and are well aware of the feelings of their students, they can even alter negative attitudes towards second language to positive ones. A dull teacher, on the other hand, would ruin the positive attitudes of learners making learning cumbersome. Language courses indirectly require the learners to adopt or incorporate the elements from other cultures. Hence, the learners have to make it the part of their behavior as to how the people from that culture, whose language they are learning, speak and behave. So it is agreed that learning another community's language is a social psychological phenomenon. Gardner (1985) regards motivation as the efforts upon a desire, with positive attitude, to achieve the target of an L2. Dornyei (2011) regards motivation as a behavior charged with persistence and energy to achieve a goal. This makes motivation an action rather than merely a desire.

The question of investigating motivation is important and it is equally important to look at the issue in the context of male-female divide in the class room. What is the social view of females in society and how females see the society expecting from them. It is due to the fact that learning any second language, for that matter English, is a point of cultural and identity interaction, and imbibing to any extent that culture's trait in repertoire or behavior is inevitable. Pakistani society has traditionally put a restricted view on changing or accepting foreign cultural norms and this becomes still stricter when the individual is a female. The social pressures are more on females than males in Pakistani society. It is because males have upper hand in social, financial, educational and other social participatory roles in society. A class room society of males and females can't evade those social psychological forces and world views. Sahiba (2009) has noted in her study on orientation for learning English among Pakistani students that integrative reasons of female students were different from males and those were desire for improving their social standing and ideas and having a broad mindedness. She further says that the participation of females is quite dismal in higher education and they have low economic and lower status than male counterparts. Pathan (2012) in his study on undergraduate students of a Pakistani university reported that females were motivated to learn English; however, they didn't think it a question of changing their own cultural values or identity.

\section{Integrative Motivation}

Integrative motivation is the most debated concept of R.C Gardner present in his socio-educational model (1985). It was introduced by Gardner and Lambert (1959-1972) to 
understand difference in L2 motivation in a multicultural setting. In his model, the variable integrativeness means a kind of interest for learning L2 with aim to have closer affinity with that cultural group. This integrativeness in turn creates integrative orientation (a reason for something or to do something) as well as a positive attitude to that cultural group. Gardner says that at an extreme level this integrativeness might terminate one's own actual cultural identity and total immersion into the cultural life style of that community. On the whole, integrative motivation, attitude to learning situation and motivation formed integrative motivation construct in the said model of Gardner. Attitude variable signifies attitude to class teacher, class fellows, syllabus or learning situation. Motivation variable signifies the amount of effort, its length of time, and amount of desire. According to Gardner, it is motivation that drives the learning process. When a person has integrative motivation, they have urge to mingle themselves with the cultural group whose language they want to learn. Gardner (2001) preferred Likert scale for measuring integrativeness that consisted of integrative orientation, interest in foreign language and attitude towards French Canadians. For the purpose, he made use of Attitude Motivation Test Battery (AMTB).

As integrativeness describes interest that is why there is goal or reason of identification with the target cultural group, the phenomenon named as integrative orientation. Noels (2001) raises two questions about integrative orientation. He says it is not universal and varies with context and then he also says that integrativeness might have various other orientations (reasons) instead of just integrative orientation. He lists goal of friendship, travel, intellectual curiosity, social prestige and other orientations responsible for interest (integrativeness) in the language of that cultural community. Clement and Kruidenier (1983) found four orientations (class of reasons) consistently in their samples. They were travel, friendship, instrumental and knowledge goals of the learners. It may be noted that Gardner (2001) makes it clear that motivation and orientations are two different things. Dornyei (2011) in his 1994 three level framework, puts the integrative orientation in his language level concept.

McClelland (2000) raised the point to define a new integrativiness that should include the world community in its meaning than particular native speakers of English. This idea gained significance. It is because the traditional integrativeness concept is context specific due to the fact that Gardner developed this concept while doing study on Anglophone and Francophone peoples in Canada. Both communities coexist and hence they can interact and contact. However, peoples living in Pakistan, India or other various countries don't have proximity with the native English cultures; hence, integrativeness needed some modification. Dornyei and Ushioda (2013) say that the globalization of English language has further diminished the idea of integrative motivation.

The latent globalized English language perception among learners and its global cultural version have been found in various studies. This gives new direction to the Gardner's definition of integrativeness. Lamb (2004) in the analysis of his qualitative part of study says that there could be seeking of bicultural identity by young Indonesian students. This bicultural identity was not native English speakers like but rather they imagined themselves a globalized version of English culture. The study was basically quantitative; however, when the integrative orientation couldn't be clear from survey the researcher turned to interviews. Some two hundred nineteen (219) students filled survey and a focal group of students 
containing twelve participants from the sample were interviewed. Chen Warden and Chang (2005) found integrative motivation non-influential; however, a requirement motivation, a type of extrinsic motivation was found. The study based on internet survey responded by five hundred sixty seven English language learners people out of which $42 \%$ was student.

Williams and Burden (1997) gave importance to individual differences based on context, situation and gender. They based their understanding on social constructivist idea of motivation. By the starting years of 2000 it was the collective emphasis that language is a social and historical phenomenon and not primarily a cognitive process. Researchers like Norton (2000) and Block (2003) emerged in the SLA field taking up this view strongly.

\section{Gender Based Differences}

Generally, it has been noted by researchers that female students show more excellence and interest than their male counterparts in second language learning. (Aacken, 1999; Dornyei \& Shoaib, 2005; Keller, 1983). Shams (2008) taking help from AMTB (Attitude Motivation Test) based his survey study in Karachi, Pakistan to investigate the difference between seventy seven (77) $8^{\text {th }}$ grade girls and boys of a private school on attitude and L2 motivation. He found girls having more positive attitude and motivation for English than boys.

Lukmani (1972) concluded in a study done on 60 Marathi speaking female high school students that there was higher instrumental orientation in them than integrative orientation. Burstall (1975 cited in Madrid, 1995) in her longitudinal study concluded that primary girls (6000 sample size) learning French as second language outperformed boys in achievement tests. She also found girls' attitude more favorable to learning French than boys. The same tendency of higher positive attitude and motivation for learning French of girls than boys was found by Gardner and Lambert (1972) in their Canadian study. Al Harthy (2017) in his study on male and female students in the Arab world says that females have shown superiority over male students in learning English. Further, the integrative part of motivation was more than male students.

Adachi (2015) conducted a study on $5^{\text {th }}$ and $6^{\text {th }}$ grade students in Japan. He found girls having higher motivational orientations (integrative and instrumental) than boys.

Xiong (2010) concluded in his study that girls have stronger motivation than boys.

Akram and Ghani (2013) indicate absence of difference on the basis of gender in cultural identity, interest in foreign languages and instrumental motivation. The participants of the study were $12^{\text {th }}$ grade students (63 male and 87 female). Their study has Pakistani context. Bacon (1992) too came up with the results that there was no significant difference in motivation between male and female participants. Saira, Nazish and Sumera (2018) conducted a study in University of Sindh Pakistan and came up with the conclusion of non-existence of worth considering difference in motivation of male and female students.

\section{Aim of Study}

There is knowledge gap on gender-wise difference in the integrative motivation while learning second language learning. This study aims to fill that gap of knowledge in the context of Shah Abdul Latif University.

\section{Hypothesis}

$\mathrm{H}_{1}$ : There is considerable difference in the mean scores of integrative motivation of male and 


\section{Macrothink}

female students for learning English.

Ho: There is no considerable difference in the mean scores of integrative motivation of male and female students for learning English.

\section{Research Question}

RQ: Is there difference in integrative motivation of male and female students for learning English?

\section{Participants}

The participants of the study were first year students of undergraduate courses studying in various departments of the university. I visited their classes after getting formal approval from teachers concerned. The number of participating students was 380 students. After conduct of survey I found 350 questionnaires fit for my analysis. The questionnaires contained 178 male students and 172 female students.

\section{Instrumentation}

I used a questionnaire whose items were either adopted or adapted looking at the local context. I adopted the items either from Attitude Motivation Test Battery (1985) or Pathan (2012) questionnaire for his study on motivation in Pakistan. There were five items on integrative motivation that were finally chosen for my questionnaire. Likert scale comprising five choices (including neutral) was used. In the pilot study the reliability statistics the Cronbach's alpha stood at 8.19 . SPSS $20^{\text {th }}$ version was used for the study.

The questionnaire includes the broadened concept of integrativeness. It covers not only Gardner's concept of similar identity or becoming closer in identity to target group but also the Dornyei's and others concept of cultural interest, travel and friendship orientationor part of imagined global community.

Table 1. Statements on integrative motivation

\begin{tabular}{|c|c|c|}
\hline No & Statement & orientation \\
\hline 1 & I want to learn English to travel to different countries. & travel \\
\hline 2 & $\begin{array}{l}\text { Studying English is necessary, it helps making friends } \\
\text { from various nations on internet. }\end{array}$ & friendship \\
\hline 3 & $\begin{array}{l}\text { Studying English is wonderful because, when I am } \\
\text { skilled, it would make me enjoy English movies and } \\
\text { songs. }\end{array}$ & "Cultural interest" \\
\hline 4 & $\begin{array}{l}\text { I want to learn English. In this way I can know English } \\
\text { speaking people better. }\end{array}$ & $\begin{array}{l}\text { Closer } \\
\text { interaction/contact }\end{array}$ \\
\hline 5 & $\begin{array}{l}\text { I want to learn English because It is my desire to be like } \\
\text { British/ Americans. }\end{array}$ & $\begin{array}{l}\text { Gardner's extrem } \\
\text { integrativeness }\end{array}$ \\
\hline
\end{tabular}

\section{Methodology}

The participants, 380 students, reported on the questionnaire measuring integrative motivation. The researcher found 350 questionnaires (178 males and 172 females) fit to be processed in SPSS $20^{\text {th }}$ version for analysis. 


\section{Data Analysis}

By taking help from SPSS $20^{\text {th }}$ version, independent Sample t-test was run for investigating significant difference in integrative motivation on gender basis. In this test gender was independent variable while integrative motivation was dependent variable. Traditionally, 0.5 is set as minimum alpha for gender difference. Therefore, this researcher followed the same alpha value for testing the hypothesis.

Table 2. Independent samples test

\section{Group Statistics}

\begin{tabular}{llllll}
\hline \multirow{4}{*}{ ave_intg } & gender & $\mathrm{N}$ & Mean & Std. Deviation & Std. Error Mean \\
& Male & 178 & 14.1584 & 4.18378 & .31359 \\
& female & 172 & 14.9907 & 3.68184 & .28074
\end{tabular}

\section{Independent Samples Test}

Levene's
Test for
Equality t-test for Equality of Means
of
Variances

95\% Confidence

F Sig. T Df Sig. Mean Std. Error Interval of the (2-tailed) Difference Difference Difference

Lower Upper

Equal

variances $2.935 .088-1.973348 \quad .049 \quad-.83227 \quad .42181 \quad-1.66190-.00265$
assumed

ave_intg Equal

variances

not

$-1.977345 .017 .049$

$-.83227 \quad .42089$

$-1.66011-.00443$

assumed

The male participants (178) scored their mean at 14.1584. The 172 female participants' mean score stood at 14.9907. The standard deviation of the two is .4 .18378 and 3.68184 respectively. Therefore, considering mean scores, no significant difference is found in integrative motivation of both the groups, males and females.

In table no. 2 significance in levene's test for equality of variances is 0.088 which is greater than 0.05 . In this way, equality of variance is accepted. [ $\mathrm{t}=-1.973$, sig (2-tailed) $=049]$.

Therefore, null hypothesis, and not alternate hypothesis, is accepted.

\section{Conclusion}

This study concludes that females or male students of Shah Abdul Latif University have no difference regarding integrative motivation for learning English. However, it has been noted that more studies need to be done on the issue. Further, in-depth investigation using qualitative methodology, can also contribute significantly. The research area in L2 motivation 
yet is deficient on gender base differences.

\section{References}

Adachi, R. (2015). Motivation and communicative attitudes among Japanese EFL pupils. Indonesian Journal of Applied Linguistics, 5(1), 1-10. https://doi.org/10.17509/ijal.v5i1.824

Akram, M., \& Ghani, M. (2013). Gender and language learning motivation. Academic Research International, 4(2), 536.

Al Harthy, S. R. (2017). English language motivation between gender and cultures. Journal of Educational and Social Research, 7(2), 123-132. https://doi.org/10.5901/jesr.2017. v7n2p123

Bacon, S. M. (1992). The relationship between gender, comprehension, processing strategies, and cognitive and affective response in foreign language listening. The modern language Journal, 76(2), 160-178. https://doi.org/10.1111/j.1540-4781.1992.tb01096.x

Chen, J. F., Warden, C. A., \& Chang, H. T. (2005). Motivators that do not motivate: The case of Chinese EFL learners and the influence of culture on motivation. TESOL Quarterly, 39(4), 609-633. https://doi.org/10.2307/3588524

Dörnyei, Z., \& Ushioda, E. (2013). Teaching and researching: Motivation. Routledge.

Gardner, R. C. (2001). Integrative motivation and second language acquisition. Motivation and Second Language Acquisition, 23, 1-19. https://doi.org/10.1037/h0086854

Hashwani, M. S. (2008). Students' attitudes, motivation and anxiety towards English language learning. Journal of Research and Reflections in Education, 2(2).

Keller, J. M. (1983). Motivational design of instruction. Instructional design theories and models: An overview of their current status, 1, 383-434.

Madrid, D. (1995). Internal and external factors affecting foreign language teaching and learning. Actas de las II Jornadas de Estudios Ingleses. Universidad de Jaén, 2(2), 59-82.

Mc Clelland, N. (2000). Goal orientations in Japanese college students learning EFL. In S. D. Cornwell, \& P. Robinson (Eds.), Individual Differences in Foreign Language Learning: Effects of Aptitude, Intelligence and Motivation (pp. 99-115). Tokyo. Japanese Association for Language Teaching.

Noels, K. A. (2001). New orientations in language learning motivation: Towards a model of intrinsic, extrinsic, and integrative orientations and motivation. Motivation and Second Language Acquisition, 23, 43-68.

Pathan, H. (2012). A Longitudinal investigation of Pakistani university students' motivation for learning English. ( $\mathrm{PhD}$ thesis. Glasgow: University of Glasgow).

Sahiba. M. (2009). Regional languages of Pakistan: Issues and concerns for language planning in higher education. In M. Sahiba, S. Aliya, H. Nasreen, \& M. A. Nasreen (Eds.) Emerging issues in TEFL, Challenges for Asia (pp. 31-58). Oxford University press. Karachi.

Shoaib, A. (2005). 3 Affect in lifelong learning: Exploring L2 motivation as a dynamic process Amel Shoaib and Zoltan Dornyei. Learners' stories: Difference and diversity in language learning, 22.

Van Aacken, S. (1999). What motivates L2 learners in acquisition of Kanji using CALL: A case study. Computer Assisted Language Learning, 12(2), 113-136. https://doi.org/10.1076/ 


\section{Macrothink}

call.12.2.113.5723

Williams, M., \& Burden, R. L. (1997). Psychology for Language Teachers: A Social Constructivist Approach. Cambridge University Press, 40 West 20th Street, New York, NY.

Xiong, X. (2010). A comparative study of boys' and girls' English study differences. Journal of Language Teaching and Research, 1(3), 309-312. https://doi.org/10.4304/jltr.1.3.309-312

\section{Copyright Disclaimer}

Copyright reserved by the author(s).

This article is an open-access article distributed under the terms and conditions of the Creative Commons Attribution license (http://creativecommons.org/licenses/by/3.0/). 